\title{
DIFFUSIVE MOTION OF IONS IN SUPERIONIC CONDUCTORS : A COMPUTER SIMULATION STUDY OF $\mathrm{CaF}_{2}($

\author{
A. RAHMAN
}

Argonne National Laboratory, Argonne, Illinois 60439, U.S.A.

\begin{abstract}
Résumé. - Les conducteurs superioniques sont caractérisés par le fait que l'un des ions, parmi deux ou plusieurs qui composent le matériau, est mobile, tandis que le système tout entier se comporte comme un solide. $\mathrm{CaF}_{2}$ est un tel matériau. Nous présentons la simulation de $\mathrm{CaF}_{2}$ sur ordinateur pour étudier les corrélations structurelles et dynamiques. Utilisant les méthodes bien connues pour traiter les systèmes ioniques [1], les calculs ont été faits pour une température de $1590 \mathrm{~K}$ et pour une densité de 2,525 g. $\mathrm{cm}^{-3}$, avec les fonctions d'interactions données par Kim et Gordon [2]. Les premiers calculs ont été faits avec $108 \mathrm{Ca}^{++}$et $216 \mathrm{~F}^{-}$placés sur les sites d'un réseau cristallin de fluorite. Les résultats montrent [3] sans ambiguité que dans ces conditions de température et de densité, les $\mathrm{Ca}^{++}$continuent à préserver leurs positions cristallines cubiques face centrée tout en participant aux mouvements thermiques, tandis que les $\mathrm{F}^{-}$n'ont plus de positions moyennes permanentes et ils possèdent une constante de diffusion égale à $2,6^{6} \times 10^{-5} \mathrm{~cm}^{2} \cdot \mathrm{s}^{-1}$, une valeur semblable à des valeurs de diffusion dans les milieux liquides. La corrélation entre les positions octaédrales du réseau des $\mathrm{Ca}^{++}$et les positions des $\mathrm{F}^{-}$montre que ces derniers utilisent les régions d'espace autour des positions octaédrales pendant leurs mouvements diffusifs.

Dans une étude plus récente [4], on a montré que le modèle de Chudley-Elliott [5] pour des sauts diffusifs est conforme au comportement à grande valeur de $t$, de la fonction $\langle\exp (i \mathbf{k} \cdot \mathbf{u}(t))\rangle, \mathbf{u}(t)$ étant le déplacement d'un $\mathrm{F}^{-}$. Les probabilités des sauts dans les directions 100 et 110 sont de 0,8 et 0,2 , le temps de résidence étant $6 \times 10^{-12} \mathrm{~s}$. De plus, il est possible de déterminer par mesures directes, le temps de vol ; ce travail est en cours.

La diffusion des $\mathrm{F}^{-}$dépend sensiblement de la densité du système. Aussi, la substitution d'un des $108 \mathrm{Ca}^{++}$par un $\mathrm{Mg}^{++}$augmente considérablement la constante de diffusion des $\mathrm{F}^{-}$. Ces travaux sont en cours.
\end{abstract}

Abstract. - Superionic conductors are characterized by the fact that one type of ion, out of the two or more ionic species which the material contains, is mobile while the system as a whole behaves as a solid. $\mathrm{CaF}_{2}$ is one such material. The talk will be concerned with a computer simulation of $\mathrm{CaF}_{2}$ to study the nature of certain structural and dynamical correlations in that material. Using well known methods for treating ionic systems [1], the calculation was made for a temperature of $1590 \mathrm{~K}$ and density of $2.525 \mathrm{~g} / \mathrm{cc}$, using the potential functions given by Kim and Gordon [2]. The calculation was initiated with the $108 \mathrm{Ca}^{++}$'s and the $216 \mathrm{~F}^{- \text {'s }}$ occupying the sites of the fluorite structure. The results show [3] quite unambiguously that under the above conditions the $\mathrm{Ca}^{++}$ions perform thermal motions around sites of an f.c.c. lattice but the $\mathrm{F}^{-}$ions have no permanent mean position and have a liquid like constant of self-diffusion, namely, $2.6 \times 10^{-5} \mathrm{~cm}^{2} \cdot \mathrm{s}^{-1}$. From the pair correlation

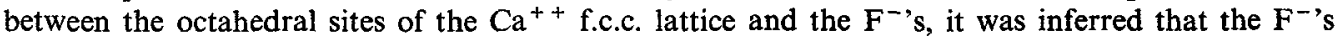
make considerable use of the octahedral sites during their diffusive motion.

In later work [4], it has been shown that the Chudley-Elliott jump diffusion model [5], suitably modified, is able to account for the long time behaviour of the function $\langle\exp (i \kappa . \mathbf{u}(t))\rangle$, $\mathbf{u}(t)$ is the displacement of an $\mathrm{F}^{-}$ion. Probabilities of jumps in the 100 and 110 directions are 0.80 and 0.20 , respectively, and the residence time $6 \times 10^{-12} \mathrm{~s}$. It is possible, by direct measurement, to determine the flight time as well ; this work is in progress.

There are indications that the $\mathrm{F}^{-}$diffusion is very sensitively dependent on the density of the system. Also, the substitution of a $\mathrm{Mg}^{++}$in place of one of the $108 \mathrm{Ca}^{++}$makes a large increase in the constant of self-diffusion. These studies are in progress.

${ }^{*}$ ) Work performed under the auspices of the U.S. Energy Research and Development Administration. 


\section{References}

[1] Woodcock, L. V., Advances in Molten Salt Chemistry, edited by Braunstein, Mamantov, and Smith (Plenum, New York) 1975, Vol. 3.

[2] Kim, Y. S., Gordon, R. G., J. Chem. Phys. 60 (1974) 4332, see tables VI and VII.
[3] Rahman, A., J. Chem. Phys. 65 (1976) 4845.

[4] IACUCCI, G. and RAHMAN, A. (in preparation).

[5] Chudley, C. T. and Elliott, R. J., Proc. Phys. Soc. London 77 (1961) 353 . 